\title{
Next-Generation Retailing In India: An Empirical Study Using Factor Analysis
}

\author{
Manju Smita Dash \\ Dept of Business Administration, Utkal University, \\ Vanivihar, Bhubaneswar-4, Orissa, INDIA. \\ Email:manjudash@ymail.com

\section{C.V. Krishna} \\ Dept of Business Administration, Utkal University, \\ Vanivihar, Bhubaneswar-4, Orissa, INDIA. \\ Email: venkatakrishnachodimella@gmail.com
}

\begin{abstract}
The retail landscape in India is changing rapidly and is being scrutinized by large scale investments by foreign and domestic players. Market liberalization and changing consumer behavior have sown the seeds of a retail transformation. Indian retailing is growing fast and imparting the consumer preferences across the country. Today retailing is largest contributing sector to country's GDP i.e. $10 \%$ as compared to $8 \%$ in China, $6 \%$ in Brazil. Modern retailing is capable of generating employment opportunities for 2.5 million people by 2010 in various retail operations and over 10 million additional workforces in retail support activities. Organized retail which presently account for only 4-6 percent of the total market is likely to increase its share to over $30 \%$ by 2013.It offers huge potential for growth in coming years. India is becoming most favore retail destination in the world.
\end{abstract}

Keywords: Organized retail, Hyper market, next generation retail, specialty stores, Supply chain.

\section{INTRODUCTION}

India is witnessing changing life styles, increased incomes, the demographic variabilities and vibrant democracy. Indian retailing is expanding and is expected to reach at US\$637 billions by 2015.Modern retail is soon capturing $22 \%$ share in total retail by 2010 with the expansion of 12 millions outlets and provision of creating 1.5 millions jobs in 2 to 3 years. The industry is playing vital role in the economic growth of the country. The concept of shopping is moving in and around hypermarkets, supermarkets, and specialty stores and in other formats. The retailing industry has been present in our country through history and is considered as one of the largest sectors in the Indian economy, contributing to around $14 \%$ to the GDP, and employing around $7 \%$ of the total population. For decades, retailing in India has been highly fragmented, i.e., unorganized, due to the presence of huge number of small mom-n-pop stores. As per Images F\&R Research 'India Retail Report 2007', organized retailing in India accounts for 4.6\% (Rs. 55,000 Crores or \$ 12.4 Billion) of Rs. 120,000 Crores or $\$ 270$ Billion retail market with an expected $40 \%$ plus annual growth rate, and is expected to grow to Rs. 2,00,000 Crores, i.e., $\$ 45$ Billion by 2010. During the period 2005- 2006, the leading retailers' sales growth was $50-100 \%$. While retailing industry is present for centuries, it is only in the recent times that it has witnessed so much dynamism and corporate attention. It is the latest bandwagon that has witnessed hordes of big players like TATA, Birla, Reliance, Pantaloon Group, etc., leaping into it. The entry of big players in retailing has caused a major revolution in its marketing strategies and innovations. Now retail sector, being considered as the most dynamic and attractive sector in India, is going through a transition phase. For a long time, the corner grocery store was the only choice available to the consumer. This is slowly giving way to international formats of retailing. The traditional food and grocery segment has seen the emergence of hypermarkets / supermarkets / grocery chains (Food World, Subhiksha, Apna Bazaar, Big Bazaar, etc.) and fast food chains (McDonalds, Dominos, etc.).The Indian Retail sector is estimated to have a market size of about $\$ 180$ billion, but the organized sector represents only $2 \%$ share of this market. Liberalization of Indian Economy has brought opening for consumer goods this has helped many MNC,s to serve with wide variety of choices to Indian consumers. Consumers has shifted there demands towards foreign brands 
like Pizza hut, Mc Donald's etc. Internet has also been an tool for this Revolution as Indian consumers are more accessible to the growing influences of domestic and foreign retail chains

The Indian retail industry is undergoing a paradigm shift and 'Next Generation Retailing' has evolved with new standards and benchmarks set for the sector, with higher and sophisticated technology at one end and increasing customer focus on the other. This article defines 'NextGeneration Retailing' and describes its characteristic features by using factor analysis and focuses on the advantages of Next Generation Retailers in the Indian context. Next-Generation Retailing is defined as the newer and younger generation of organized retail industry evolution which is multidimensional and far more advanced when compared to its previous generations. 'Next-Generation Retailing' has evolved finally, and its important characteristic features are: High-end technology, experimenting with innovative formats and enhanced customer centricity for building a loyal clientele. According to a report by Ernst and Young, currently, the Indian organized retail sector is in its third phase of evolution wherein the retailers are focusing on end-to-end supply chain management, backend operation, and technology and process improvements. And finally, the Next-Generation is challenging the older and much stronger unorganized retail.

\section{LITERATURE REVIEW}

India is being seen as a potential goldmine for retail investors from over the world and latest research has rated India as the top destination for retailers for an attractive emerging retail market. India's vast middle class and its almost untapped retail industry are key attractions for global retail giants wanting to enter newer markets. Even though India has well over 5 million retail outlets, the country sorely lacks anything that can resemble a retailing industry in the modern sense of the term. This presents international retailing specialists with a great opportunity. The organized retail sector is expected to grow stronger than GDP growth in the next five years driven by changing lifestyles, burgeoning income and favorable demographic outline

Mohanty \& Panda (2008) opines about retailing as a sector of India occupies important place in the socio-economic growth strategy of the country. India is witnessing retailing boom being propelled by increasing urbanization, rising purchasing power parity (PPP) of ever growing India's middle class, changing demographic profiles heavily titled young population, technological revolution, intense globalization drive etc.

Sahu (2010) describes that a rise in consumer confidence, improvement in profitability and aggressive expansion plans signal better tidings for listed players in the organized retail space. Moreover, analysts believe listed retailers could attract foreign investments by spinning off their subsidiaries into separate companies which can provide a great opportunity for the improvement of this sector.

Gellner (2007) explains in this context that in most retail meetings and/or publications, hardly ever is there any talk on problems that modern retail formats are encountering doing business in India. There is a significant profitability challenge, to deliver the brand promise in terms of quality and geographic spread in line with the growth in consumer demand.

Nagesh (2007) describes that Indian retailing will see a sea of change in the next five years, driving consumption boom never seen in the history of any country. From a drout situation we will see a flood of modern retail, So Indian retail will be on a steady ground of sustained growth year after year and thereafter.

Akash (2009) says that Retail business in India, as anywhere else in the world, plays a crucial role in an economy. Retail in India has the potential to add value over Rs 2,00,000 crore (\$45billion)business by the year 2010 generating employment for some 2.5 million people in various retail operations and over10 million additional workforce in retail support activities including contract production and processing, supply chain and logistics, retail real estate development and management. Gibson, CEO Retail Association Of India opines (2007) that modern retailing today is growing faster than expected while the current growth rate is around 30 percent, the sector is expected to grow at 40 50percent on a year basis.

Shivkumar, Executive Director and leader of Retail and Consumer Practices Price Warehouse Co-operatives,(2009)also holds the opinion that retailing is the next sunrise segment of the economic development of the country. 
Mishra (2008) says, there is a hectic activity in the sector in terms of expansion, entry of international brands and retailers as well as focus on technology, operations, infrastructure and processes. All these present a tremendous opportunity in this high growth industry.

Yuvarani (2010) opines that according to a study the size of the Indian Retail market is currently estimated at Rs 704 corers which accounts for a meager 3\% of the total retail market. As the market becomes more and more organized the Indian retail industry will gain greater worth. However, the future is promising, the market is growing, government policies are becoming more favorable and emerging technologies are facilitating operations.

Biyani (2007) describes that we are on the cusp of change wherein a huge, multicultural India is transforming from a socialist economy to a consumption-led, creative economy. The scope and depth of change that is taking place due to the revolutionary retail market with a gigantic opportunity for marketers and retailers, not only in large cities but also in small towns. So retailing can play a significant role in creating the India of tomorrow.

Kearney (2007) explains that the retail sector provides a unique platform to India .Government, both central and state, need to engage with the sector and utilize its potential for social development. So the Indian market and its consumers poised for a retail consumption explosion that will continue for future.

India's sunrise retail sector is witnessing a major transformation as traditional markets make way for modern and indigenously development retail formats. Standing on the threshold of a retail revolution and witnessing a fast changing retail landscape. Indian retail is still growing, and growing at an enviable rate. In the new era of liberalization, there exists immense opportunities for retail business .Progressive policies, economic and political stability, liberal policies on technology, changing consumers profile and demographic character, increasing urbanization, improved infrastructure, increasing number of nuclear families, increasing working women population are new opportunities. Bulging of middle and upper middle classes, whose purchasing power is now substantial and turning Indian economy as the fourth largest economy in the world in terms of purchasing power, are opportunities galore for giving further boost to retail business in India.

\section{OBJECTIVES AND METHODOLOGY}

The main objectives of this article are:

- To define Next-Generation Retailing

- To identify the characteristic features of Next-Generation Retailing

- To find out the factors of Next-Generation Retailing

- To identify the advantages of Next-Generation Retailing

1. Sample Size: 200

2. Sampling Method: Simple random sampling

3. Sample Population: Consumers

4. Sampling Data: Primary field survey data

5. Sampling Area: Visakhapatnam

\section{India - The Global Potential Market for Retailing}

Retailing is the world's largest private industry with total sales of $\$ 6.6 \mathrm{tn}$. In India too, the industry is large, accounting for around $10 \%$ of GDP, which is the second largest after agriculture. Annual retail sales in India are estimated at $\$ 340$ bn and have been growing at 5\% annually. India has one of the highest densities of retail outlets in the entire world. There are more than 12 million retail outlets (including unorganized ones) in the country. Over the past decade, there has been rapid expansion of organized retail formats. The organized retail space had increased to 16 million sq $\mathrm{ft}$ in 2008 from barely 1 million sq $\mathrm{ft}$ in 2002 . The customer profile too is quite young and spending patterns have shifted upwards, thus creating a growing opportunity for the retailers to serve and delight the customers. While $50 \%$ of India's population is less than 25 years old, $70 \%$ is less than 35 years of age. The implication is that there is a large complement of young working population, thus, resulting in increased retail spending.

The Indian market is quite lucrative for global players in the retail sector, and India has been placed at second position in AT Kearney's annual Global Retail Development Index (GRDI) 2008. As the contemporary retail sector in India is reflected in sprawling shopping centers, multiplex- malls and 
huge complexes offer shopping, entertainment and food all under one roof, the concept of shopping has altered in terms of format and consumer buying behavior, ushering in a revolution in shopping in India. This has also contributed to large-scale investments in the real estate sector with major national and global players investing in developing the infrastructure and construction of the retailing business. The trends that are driving the growth of the retail sector in India are

- $\quad$ Low share of organized retailing

- $\quad$ Falling real estate prices

- Increase in disposable income and customer aspiration

- Increase in expenditure for luxury items (CHART)

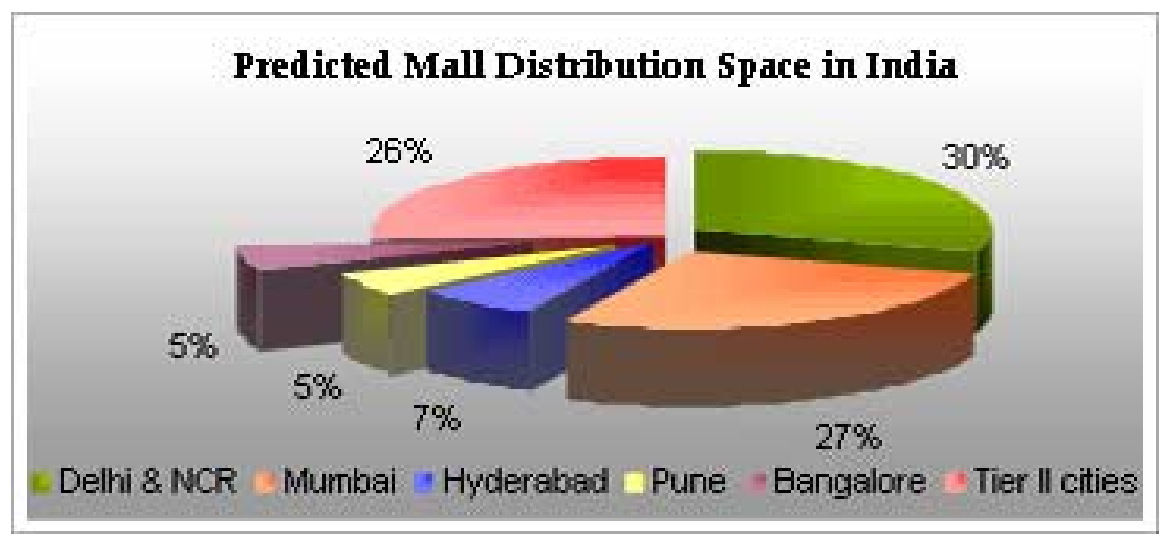

Another credible factor in the prospects of the retail sector in India is the increase in the young working population. In India, hefty pay packets, nuclear families in urban areas, along with increasing working-women population and emerging opportunities in the services sector. These key factors have been the growth drivers of the organized retail sector in India which now boast of retailing almost all the preferences of life - Apparel \& Accessories, Appliances, Electronics, Cosmetics and Toiletries, Home \& Office Products, Travel and Leisure and many more. With this the retail sector in India is witnessing rejuvenation as traditional markets make way for new formats such as departmental stores, hypermarkets, supermarkets and specialty stores. The retailing configuration in India is fast developing as shopping malls are increasingly becoming familiar in large cities. When it comes to development of retail space specially the malls, the Tier II cities are no longer behind in the race. If development plans till 2007 is studied it shows the projection of 220 shopping malls, with 139 malls in metros and the remaining 81 in the Tier II cities. The government of states like Delhi and National Capital Region (NCR) are very upbeat about permitting the use of land for commercial development thus increasing the availability of land for retail space; thus making NCR render to $50 \%$ of the malls in India.

\section{The Story of Organized Retail}

Even though the Indian market holds a lot of promise, the penetration of organized retail has been comparatively quite low in India. India is a nation of traditional mom and pop stores, which have an extensive reach, and have been ruling the retail sector for many years. The traditional unorganized retail outlets provide customized services to their small local clientele, including credit sales and home delivery. However, the entry of many organized retail chains, some of which are promoted by major Indian corporate houses, is posing a threat to the traditional retailers. These new retailers are experimenting with a multitude of formats, and are trying to build a strong base with superior technology and high sense of customer centricity. The organized retailers aim to capture a progressively increasing share of the total retail pie. The large number of players entering organized retail at such a pace is a cause of concern for the unorganized retailers. From a fresh entrant like Reliance Fresh, to a pioneer, like Pantaloon Retail India Limited (PRIL), all the organized retailers are upgrading and equipping themselves to capture the attention of prospective customers. 'NextGeneration Retailing' has finally emerged on the scene and the retail industry is moving ahead at a new pace. Shoppers are seen being delighted by the 'shoppertainment' that they are currently experiencing, and they are finding their own way of getting served better in the way they want. 


\section{Evolution of Indian Organized Retailing}

The development of organized retail started comparatively late in India. Single brand retail chains (such as those of Raymond's, Liberty footwear and such others) began to find a foothold in the major metros during the 1980s. Multi-brand retail chains came into the picture mainly during the 1990s. Shopping centers began to come up around 1995. Shopping malls and hyper markets have begun to evolve primarily during the new millennium. Now, several large Indian business houses have made a foray into retailing, with multiple formats and in varied product categories. Multinational retailers are also trying to edge their way into the Indian market in whatsoever manner the present foreign investment norms permit. International retail chains, such as Wal-Mart, Tesco, etc., are waiting in the wings for Foreign Direct Investment (FDI) being allowed in multi-brand retailing. Exhibit 1 shows different phases in the growth of organized retailing in India during the new millennium.

\begin{tabular}{|c|c|c|}
\hline \multicolumn{3}{|c|}{ Exhthit 1: Development of Organired Retail in India Since 2000} \\
\hline Year & Growth & Developments \\
\hline 2000 & First Phase & Entry, Growth, Expansion, Top line focus \\
\hline 2005 & Second Phase & Range, Portfolio, Far more options \\
\hline 2008 & Third Phase & $\begin{array}{l}\text { End-to-end supply chain management, Backend operation, } \\
\text { Technology, Process }\end{array}$ \\
\hline 2011 & Fourth Phase & Mergers and Acquistions, Shakeout and Consolidation, High Investment \\
\hline & & Source: Emst \& Young: wwwe\&y.com \\
\hline
\end{tabular}

As shown in Exhibit 1, since the dawn of the new millennium, organized retail in India has shown three phases of development, while we are anticipating a fourth one:

1. First Phase: This was the starting point for the take-off of organized retailing, where the main focus areas were entry, growth and expansion strategies, with importance being accorded to top line revenue growth.

2. Second Phase: In this phase, the focus shifted to expanding the product range and geographic reach by building a wider network of outlets.

3. Third Phase: This is the current phase, projected to continue up to the year 2011. In this phase, the emphasis is on technological enhancements, supply chain management, backend operations, and technology and process improvement. This phase may be considered as the first stage of 'NextGeneration Retailing.'

4. Fourth Phase: In the fourth phase, many decisive changes are anticipated. These include mergers and acquisitions, consolidations and shakeouts, involving huge investments.

\section{EMPIRICAL ANALYSIS}

Given this background, a sample of 200 consumers was surveyed to explore the characteristic features of 'Next-Generation Retailing' with the help of Factor Analysis. All the 200 respondents were surveyed on 14 variables listed in Exhibit 2, to know how they rate each variable as being a characteristic feature of 'Next-Generation Retailing.' The rating was done on a five-point semantic differential scale, ranging from 'strongly agree' to 'strongly disagree.' The survey data was analyzed by Factor Analysis through Principal Component Analysis Extraction Method using SPSS Version 15.0. Some of the results obtained are summarized in Exhibits 3 to 6.

Finally, three factors are extracted by this method. Factor Analysis clearly demarcates the important dimensions for 'Next-Generation Retailers', as the results clearly show that the 14 variables can be grouped into three factors or dimensions that best explain 'Next-Generation Retailing'. The three important dimensions of 'Next-Generation Retailers' are:

\section{Technology}

a. Sophisticated Information Management System (Factor Loading $=\mathbf{0 . 5 3 9})$

b. Computerized Inventory Management System (Factor Loading $=\mathbf{- 0 . 5 6 5}$ )

c. Strong Supply Chain (Factor Loading $=\mathbf{0 . 6 5 5}$ ) 
d. Speedier Processing (Factor Loading $=\mathbf{0 . 7 7 0}$ )

e. Electronic Billing (Factor Loading $=\mathbf{- 0 . 8 2 8}$ )

\section{Innovative Format Decisions}

a. New and Improved Merchandize Lines $($ Factor Loading $=\mathbf{0 . 5 5 3}$ )

b. Newer Locations (Factor Loading $=\mathbf{0 . 7 1 2}$ )

c. Variety of Assortments (Factor Loading $=\mathbf{- 0 . 5 8 8}$ )

d. Experiment Different Sizes (Factor Loading $=\mathbf{- 0 . 3 7 1}$ )

e. Attractive Visual Merchandizing (Factor Loading $=\mathbf{- 0 . 7 0 8}$ )

3. Customer Centricity

a. Customer Friendly (Factor Loading $=\mathbf{0 . 1 8 0})$

b. Exceeding Customer Expectations (Factor Loading = -0.603)

c. Providing Rich Customer Experience (Factor Loading $=\mathbf{0 . 7 3 9}$ )

d. More Value for Money (Factor Loading $=\mathbf{0 . 7 5 0}$ )

\begin{tabular}{|l|l|}
$\begin{array}{c}\text { Exhibit 2a Voriables Used to Explore the } \\
\text { Chorodteristics of 'llext-Generotion } \\
\text { Retoiling' }\end{array}$ \\
\hline \begin{tabular}{l|l} 
SI. \\
No.
\end{tabular} & \multicolumn{1}{|c|}{ Variable } \\
\hline 1 & $\begin{array}{l}\text { Sophisticated information } \\
\text { management system }\end{array}$ \\
\hline 2 & $\begin{array}{l}\text { Computerized inventory management } \\
\text { system }\end{array}$ \\
\hline 3 & Strong supply chain \\
\hline 4 & Speedier processing \\
\hline 5 & Electronic billing \\
\hline 6 & New and improved merchandize lines \\
\hline 7 & Newer locations \\
\hline 8 & Variety of assortments \\
\hline 9 & Experiment different sizes \\
\hline 10 & Attractive visual merchandizing \\
\hline 11 & Customer friendly \\
\hline 12 & Exceeding customer expectations \\
\hline 13 & Providing rich customer experience \\
\hline 14 & More value for money \\
\hline
\end{tabular}




\begin{tabular}{|c|c|c|c|c|c|c|c|c|c|c|c|c|c|c|}
\hline \multicolumn{15}{|c|}{ Correlation between Veclors of Values } \\
\hline & 1 & 2 & 3 & 4 & 5 & 6 & 7 & 8 & 9 & 10 & 11 & 12 & 13 & 14 \\
\hline 1 & 1.000 & 0.048 & 0.356 & 0.509 & -0.535 & -0.429 & 0.048 & -0.089 & 0.356 & -0.089 & 0.048 & 0.048 & -0.089 & 0.048 \\
\hline 2 & & 1.000 & -0.089 & -0.218 & 0.356 & 0.048 & 0.048 & -0.089 & 0.356 & -0.535 & $5-0.429$ & $9-0.429$ & 0.356 & 0.048 \\
\hline 3 & & & 1.000 & 0.408 & -0.667 & -0.089 & -0.089 & 0.167 & 0.167 & 0.167 & -0.089 & 90.356 & 0.167 & -0.089 \\
\hline 4 & & & & 1.000 & -0.612 & -0.218 & -0.218 & 0.408 & -0.272 & 0.408 & 0.145 & 0.145 & 0.068 & 0.145 \\
\hline 5 & & & & & 1.000 & -0.089 & -0.089 & 0.167 & -0.250 & -0.667 & -0.089 & $9-0.089$ & 0.167 & -0.089 \\
\hline 6 & & & & & & 1.000 & 0.048 & -0.535 & $5-0.089$ & 0.356 & 0.048 & -0.429 & 0.356 & 0.048 \\
\hline 7 & & & & & & & 1.000 & -0.535 & $5-0.089$ & 0.356 & 0.524 & -0.429 & -0.089 & -0.429 \\
\hline 8 & & & & & & & & 1.000 & -0.250 & -0.250 & -0.089 & 0.356 & 0.167 & 0.356 \\
\hline 9 & & & & & & & & & 1.000 & -0.250 & -0.535 & 5-0.089- & -0.250 & 0.356 \\
\hline 10 & & & & & & & & & & 1.000 & 0.356 & -0.089 & -0.250 & $0-0.089$ \\
\hline 11 & & & & & & & & & & & 1.000 & -0.429 & 0.356 & 0.048 \\
\hline 12 & & & & & & & & & & & & 1.000 & -0.535 & $5-0.429$ \\
\hline 13 & & & & & & & & & & & & & 1.000 & 0.356 \\
\hline 14 & & & & & & & & & & & & & & 1.000 \\
\hline
\end{tabular}

\begin{tabular}{|l|c|c|}
\hline \multicolumn{3}{|c|}{ Exhïbit 48 Communclities } \\
\hline & Initial & Extraction \\
\hline Sophisticated Information Management System & 1.000 & 0.410 \\
\hline Computerized Inventory Management System & 1.000 & 0.528 \\
\hline Strong Supply Chain & 1.000 & 0.501 \\
\hline Speedier Processing & 1.000 & 0.728 \\
\hline Electronic Billing & 1.000 & 0.829 \\
\hline New and Improved Merchandize Lines & 1.000 & 0.439 \\
\hline Newer Locations & 1.000 & 0.557 \\
\hline Variety of Assortments & 1.000 & 0.437 \\
\hline Experiment Different Sizes & 1.000 & 0.190 \\
\hline Attractive Visual Merchandizing & 1.000 & 0.780 \\
\hline Customer Friendly & 1.000 & 0.554 \\
\hline Exceeding Customer Expectations & 1.000 & 0.902 \\
\hline Providing Rich Customer Experience & 1.000 & 0.668 \\
\hline More Value for Money & 1.000 & 0.605 \\
\hline
\end{tabular}




\begin{tabular}{|c|c|c|c|c|c|c|}
\hline \multicolumn{7}{|c|}{ Exhibit 5: Total Variance Explained } \\
\hline \multirow[t]{2}{*}{ Component } & \multicolumn{3}{|c|}{ Initial Eigen Values } & \multicolumn{3}{|c|}{$\begin{array}{l}\text { Extraction Sums of } \\
\text { Squared Loadings }\end{array}$} \\
\hline & Total & $\begin{array}{c}\% \text { of } \\
\text { Variance }\end{array}$ & $\begin{array}{c}\text { Cumulative } \\
\%\end{array}$ & Total & $\begin{array}{l}\% \text { of } \\
\text { Variance }\end{array}$ & $\begin{array}{c}\text { Cumulative } \\
\%\end{array}$ \\
\hline 1 & 3.123 & 22.305 & 22.305 & 3.123 & 22.305 & 22.305 \\
\hline 2 & 2.846 & 20.332 & 42.636 & 2.846 & 20.332 & 42.636 \\
\hline 3 & 2.158 & 15.412 & 58.048 & 2.158 & 15.412 & 58.048 \\
\hline 4 & 2.090 & 14.930 & 72.978 & & & \\
\hline 5 & 1.415 & 10.109 & 83.087 & & & \\
\hline 6 & 1.122 & 8.016 & 91.103 & & & \\
\hline 7 & 0.660 & 4.713 & 95.816 & & & \\
\hline 8 & 0.540 & 3.855 & 99.672 & & & \\
\hline 9 & 0.046 & 0.328 & 100.000 & & & \\
\hline 10 & 1.17E-016 & 8.38E-016 & 100.000 & & & \\
\hline 11 & 7.95E-018 & $5.68 \mathrm{E}-017$ & 100.000 & & & \\
\hline 12 & $-7.88 \mathrm{E}-017$ & $-5.63 \mathrm{E}-016$ & 100.000 & & & \\
\hline 13 & $-1.21 \mathrm{E}-016$ & $-8.62 \mathrm{E}-016$ & 100.000 & & & \\
\hline 14 & $-2.32 \mathrm{E}-016$ & $-1.65 \mathrm{E}-015$ & 100.000 & & & \\
\hline
\end{tabular}

\begin{tabular}{|l|c|c|c|}
\hline \multicolumn{4}{|c|}{ Exh'bif G: Component Molrix } \\
\hline & 1 & 2 & 3 \\
\hline Sophisticated Information Management System & 0.539 & -0.144 & 0.314 \\
\hline Computerized Inventory Management System & -0.565 & -0.287 & 0.355 \\
\hline Strong Supply Chain & 0.655 & -0.112 & 0.245 \\
\hline Speedier Processing & 0.770 & -0.002 & 0.367 \\
\hline Electronic Billing & -0.828 & -0.279 & -0.256 \\
\hline New and Improved Merchandize Lines & -0.319 & 0.553 & 0.174 \\
\hline Newer Locations & -0.101 & 0.712 & -0.200 \\
\hline Variety of Assortments & 0.229 & -0.588 & 0.197 \\
\hline Experiment Different Sizes & -0.042 & -0.371 & 0.224 \\
\hline Attractive Visual Merchandizing & 0.520 & 0.708 & -0.091 \\
\hline Customer Friendly & 0.085 & 0.717 & 0.180 \\
\hline Exceeding Customer Expectations & 0.504 & -0.533 & -0.603 \\
\hline Providing Rich Customer Experience & -0.319 & 0.145 & 0.739 \\
\hline More Value for Money & -0.071 & -0.192 & 0.750 \\
\hline
\end{tabular}


Based on the above, 'Next-Generation Retailing' is defined as "the newer and younger generation of organized retail industry evolution which is multidimensional and far more advanced than its previous generations." The important dimensions of 'Next-Generation Retailing', referred to as 'the three dimensions' that are making it unique and enabling it to stay ahead of the previous generations, are:

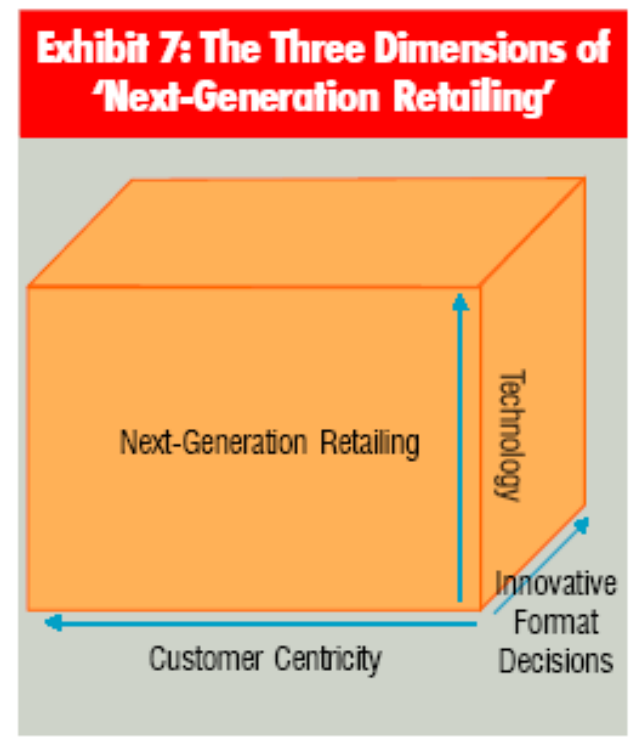

1. Technology

2. Innovative Format Decisions

3. Customer Centricity

The Next-Generation Retailers stay ahead of the previous generations by advancing along these three dimensions and thereby pose a stiff competition to others. The three dimensions of 'Next-Generation Retailing' are shown diagrammatically in Exhibit 7. The concept, definition, dimensions and diagram pertaining to 'Next-Generation Retailing' are developed, based on the results of the field survey and factor analysis.

\section{CHALLENGES \& OPPORTUNITIES}

Retailing has seen such a transformation over the past decade that its very definition has undergone a sea change. No longer can a manufacturer rely on sales to take place by ensuring mere availability of his product. Today, retailing is about so much more than mere merchandising. It is about casting customers in a story, reflecting their desires and aspirations, and forging long-lasting relationships. As the Indian consumer evolves they expect more and more at each and every time when they steps into a store. Retail today has changed from selling a product or a service to selling a hope, an aspiration and above all an experience that a consumer would like to repeat. For manufacturers and service providers the emerging opportunities in urban markets seem to lie in capturing and delivering better value to the customers through retail. For instance, in Chennai CavinKare,s LimeLite, Marico's, Kaya Skin Clinic and Apollo Hospital's Apollo Pharmacies are examples, to name a few, where manufacturers/service providers combine their own manufactured products and services with those of others to generate value hitherto unknown. The last mile connect seems to be increasingly lively and experiential. Also, manufacturers and service providers face an exploding rural market yet only marginally tapped due to difficulties in rural retailing. Only innovative concepts and models may survive the test of time and investments. However, manufacturers and service providers will also increasingly face a host of specialist retailers, who are characterized by use of modern management techniques, backed with seemingly unlimited financial resources. Organized retail appears inevitable. Retailing in India is currently estimated to be a US\$200 billion industry, of which organized retailing makes up a paltry 3 percent or US\$ 6.4 billion. By 2010, organized retail is projected to reach US\$23 billion. For retail industry in India, things have never looked better and brighter. Challenges to the manufacturers and service providers would abound when market power shifts to organized retail. 


\section{Organized retailing in India: trend of 21 st century}

From mandis to malls, Indian retailing has come a long way. The transformation of Indian retailing is to be noticed, especially with the Indian economy playing a crucial role globally. With food and oil prices rising internationally, the retail sector worldwide has been impacted. To develop a better understanding of the key challenges in the retailing sector and to discuss and debate on the strategies for combating challenges faced by the Indian retail sector, Confederation of Indian Industry (CII) with Deloitte as the Knowledge Partner organized a retail conference "Transforming Retailing in India" in Mumbai. Speaking on global trends, strategies and outlook in the retail segment in the 21 st century was Dr Ira Kalish, Director, Deloitte Research. Differentiation, branding, compelling customer experience, exploring commoditization, share of purchasing power, and continuous innovation would be the key retail strategies to be focused on in the 21st century, highlighted Dr Kalish. He further spoke on the growing impact of the internet on global retailing, including the gradual decline in store visits, slower growth of same store sales, increase in internet shopping from $0 \%-5 \%$ in the last 10 years in the US and bigger increase in internet research. Incremental spending on innovative products, focus on health, wellness and focus on social responsibility are the main challenges in global retail, stressed the Speaker. Present at the CII Conference was Mr Shyamak Tata, Partner, Deloitte Haskins $\&$ Sells who in his address dealt with the challenges and opportunities faced by the Indian retail industry.

Mr Tata said that out of the Indian GDP of about $\$ 1036$ bn in 2007, retail was about $\$ 295$ bn. Organized retail penetration has increased from 3\% in 2004 to $8 \%$ in 2007, Mr Tata said. He further elaborated on some key trends in the Indian retail industry as real estate, innovation, retail formats and consolidation and collaboration. Mr Tata spoke on the major challenges faced by the Indian retail sector as decisions on diversification, environment, location, operations, innovations, talent, technology and competition from new entrants. Whether organized retail penetration in 2011 would be $25 \%$ was the key question raised by Mr Tata.

\section{The Future Ahead}

'Next-Generation Retailing' has a long and promising future ahead, as it has started late in India and is as yet in a nascent stage. Technology is going to be the crucial factor in the development of retail in India, which will get even stronger and the backend supply chain will also become more robust in the near future. There will be even more new formats, and focus on customer centricity will increase further. Customers would thereby enjoy the full benefits of 'Next-Generation Retailing' in India.

'Next-Generation Retailing' has evolved from different stages and is expanding further with three important dimensions-technology, innovative format decisions, and customer centricity. The 'Next-Generation Retailers' are on the high edge of technology adoption and because of this, they are poised to expand rapidly as more of time and resources are saved by technology, and one can even get the exact pulse of the customers by using different information systems. Also, the 'Next-Generation Retailers' are at an advantage because of a wide variety of format options, thereby offering greater choice for customers and a wide range of products under one roof. The attractive and comfortable ambience would help to exceed customer expectations through better service delivery.

\section{CONCLUSION}

The retail sector has played a phenomenal role throughout the world in increasing productivity of consumer goods and services. It is also the second largest industry in US in terms of numbers of employees and establishments. There is no denying the fact that most of the developed economies are very much relying on their retail sector as a locomotive of growth. The India Retail Industry is the largest among all the industries, accounting for over 10 per cent of the country's GDP and around 8 per cent of the employment. The Retail Industry in India has come forth as one of the most dynamic and fast paced industries with several players entering the market. But all of them have not yet tasted success because of the heavy initial investments that are required to break even with other companies and compete with them. The India Retail Industry is gradually inching its way towards becoming the next boom industry. The Retail Industry in India has come forth as one of the most dynamic and fast paced industries with several players entering the market. But all of them have not yet tasted success because of the heavy initial investments that are required to break even with other companies and 
compete with them. The India Retail Industry is gradually inching its way towards becoming the next boom industry.

\section{REFERENCES}

Akash, S.B. (2009), Opportunities and challenges of retailing Business In India-An Explanatory Study, KAIL Journal of Management And Research, 2(1).

Biyani, K. (2007), CEO, Future Group "Retailing in the creative economy", India Retail Report, An Images F\&R Research, pp.330-333. Available at: www.indiaretailing.com

Gellner, A. (2007), The sportswear Retail segment: Problems \& Prospects, India Retail Report, An Images F\& R Research, pp.202-204. Available at: www.indiaretailing.com

Gibson,G. (2007) 'Who will buy the Most? Business Line, (Brand Line) p.1.

Kearney, A.T. (2007) India: The next retail growth story', India retail report, An Images F\&R Research,pp.228-233. Available at: www.indiaretailing.com

Mohanty, A.K.\& Panda, J. (2008), Retailing in India: Challenges and Opportunities, The Orissa Journal of Commerce, Vol. XXIX, NO.2, Bhubaneswar, July, pp. 69-79.

Nagesh, B.S (2007), Indian Retail The Way Forward, India Retail Report, An Images F \& R Research,pp.246-248,www.indiaretailing.com.

Panda,A.K.\&Mohanty,S.(2008),Emerging Retail Trends in India, The Orissa Journal of Commerce, Vol.XXIX, NO.2, Bhubaneswar, July, pp.81-89.

Sahu, R.P. (2010), Higher Sales Boost Retail, Business Standard, section II, 21.

Shivkumar, S(2009), Executive Director, Retail and Consumer Practices Price Warehouse Cooperative, India Retail Report, An Images F\&R Research, pp.6. Available at: www.indiaretailing.com

Yuvarani, R. (2010), Future Trends of Retail in India, edit online article: www.articlesbase.com 